\title{
Księgozbiory szlachty na południowo-wschodnich ziemiach dawnej Rzeczypospolitej. Kartki z dziejów
}

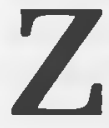
najomość dziejów książki i jej roli w dawnej Rzeczypospolitej nie będzie pełna, jeżeli nie uwzględni się wszystkich jej terenów w jej granicach historycznych. Trudności związane $z$ kwerendami w archiwach i bibliotekach znajdujących się na obszarach, które nie należą obecnie do Polski, spowodowały opóźnienie badań nad kulturą książki również na południowowschodnich ziemiach Rzeczpospolitej szlacheckiej (województwa ruskie i bełskie). Nasze dotychczasowe wiadomości, niestety, dotyczą tylko pewnych wycinkowych faktów $z$ dziejów książki zarówno odnośnie przedstawicieli stanu szlacheckiego, jak i mieszczan. Odnalezienie i opracowanie nowych dokumentów umożliwia wyrobienie sobie ogólniejszego poglądu, a to otwiera perspektywy późniejszej syntezy.

Przegląd kilkunastu księgozbiorów magnackich i szlacheckich zacznę od stwierdzenia kilku faktów. Księgozbiory XIX-i XX-wieczne (do 1939 r.) wykazały sporo starych druków $z$ proweniencjami dawnych właścicieli. Również wydane krajowe i zagraniczne katalogi dowiodły, iz na tych terenach znajclowało się sporo bibliotek instytucjonalnych i prywatnych. Niektóre publikacje (zwłaszcza Urszuli Paszkiewicz) ${ }^{1}$ dowodzą wielkości bibliotek szlacheckich. Sporo inwentarzy bibliotek świadczących o zawartości i strukturach kolekcji książkowych zalega w archiwach, zwłaszcza w materiałach XVII-wiecznych, kiedy kolekcjonerstwo szlachty (głownie magnaterii) odbywało się na więlkszą skalę niż wcześniej.

Malo jednak wiemy o bibliotekach szlacheckich w XVI w., w tym złotym wieku kultury, który poniekąd trwał jeszcze przynajmniej w pierwszych dziesięcioleciach następnego stulecia. Wojny połowy XVII w. oraz chyląca się w późniejszym czasie ku upadkowi Rzeczpospolita nie sprzyjały tworzeniu większych bibliotek.

O gromadzeniu księgøzbiorów w XVI w. może świadczyć fakt, iż na dalekim Podolu, w okolicach Baru pożyczano książki, m.in. Reja, Wujka, Groickiego jakieś Statuta a szlachcic Sebastian Karaczowski posiadał księgozbiór składający się z kilkuset książek. Książka na przełomie XVI i XVII w. znajdowała się w posiadaniu glównie bogatej szlachty $z$ terenów Rusi Czerwonej, przede wszystkim: Sieniawskich, Potockich, Golskich, Siemieńskich, Łużeckich, Danilowiczów, Kalinowskich, Lanckorońskich, Jazłowieckich, Sobieskich, Firlejów, Chodorowskich, Gołogórskich i in. ${ }^{2}$.

W Zamościu kanclerz Jan Zamoyski założyl prywatną bibliotekę, do której sprowadzał rzadkie wydania. Gromadził głównie $z$ zakresu prawa i historii. Do księgozbioru trafil fragment biblioteki Zygmunta Augusta. Zamoyski posiadał 
superexlibris, co świadczy o jego nieprzeciętnym bibliofilstwie. Księgozbiór pałacowy powiększał syn Tomasz, który gromadził książki z zakresu architektury i matematyki, natomiast wnuk kanclerza Jan - literaturę rozrywkową. W $1751 \mathrm{r}$. inwentarz tej biblioteki doprowadzony do litery S liczył 1306 woluminów druków i kilkadziesiąt rękopisów ${ }^{3}$.

Zniszczeniu uległy biblioteki w czasie działań wojennych a i zainteresowanie książką mogło być mniejsze po klęskach żywiołowych, napadach tatarskich, tureckich i innych. Posiadamy wiadomości o takich zniszczeniach z polowy XVII w., z czasów pochodów Chmielnickiego, kiedy ulegały rabunkowi wielkie i nieduże (składające się z kilku czy kilkunastu książek) zbiorki niebogatej czy średniej szlachty. Wyclaje się, iż w tym czasie najwięlisze biblioteki dlomowe liczyły po kilkaset woluminów. I tak w pierwszej połowie tego wieku na zamku w Krasiczynie znajdowało się 100 dzieł $^{4}$.

Więcej posiadał w 1658 r. Jan Aleksander Daniłowicz czerwonogrodzki starościc bo ok. 120 książek ${ }^{5}$, prawie wszystkie lacińskie z różnych clzierlzin (religia, historia, geografia, polityka, literatura klasyczna). Daniłowicz był krewnym Sobieskich i do nich być może trafiły niektóre książki należące wcześniej do starościca. Wniosek taki można wyciągnąć na podstawie tego, że tytuły co najmniej kilkunastu książek, pochodzących $z$ działu majątkowego Jana Aleksandra figurują w inwentarzach biblioteki Jana III Sobieskiego.

Książki w spisie syna starosty czerwonogrodzkiego zostały oszacowane, przy czym należy zaznaczyć, iż niektóre pozycje zostały wycenione bardzo wysoko. Najiroższe (w cenie $50 \mathrm{złp}$ ) okazały się dwa tomy Drexeliusa, zapewne Opera oraz rzecz zatytułowana "Americae seu Italiae civitatum descriptio" wyceniona na $40 \mathrm{złp.} \mathrm{Dla} \mathrm{porównania} \mathrm{dodajmy,} \mathrm{iż} \mathrm{najdroższy} \mathrm{„Obraz} \mathrm{coronatio-}$ nis BV Mariae na srebrze" figurujący w tym inwentarzu zostal wyceniony na 70 złp, a „kulbaka aksamitna" - 180 złp.

Z poloników w spisie figurują m.in. dzieła Stanisława Łubieńskiego (zatytułowane „Historia”, zapewne chodzi o Opera posthuma wydane w Antwerpii w 1643 r.), Samuela Twardowskiego (Przeważna legacyja Jaśnie Oświeconego Krzysztofa Zbaraskiego...), Jakuba Sobieskiego (De bello Chotinensi). Przewazała literatura polityczna i historyczna oraz religijna. Oprócz tego figurują dzieła $z$ zakresu literatury pięknej, astronomii i geografii. Była to jedna część całego majątku przeznaczonego do podziału. Przypuszczalnie na calość biblioteki tej gałęzi Daniłowiczów składało się kilkaset woluminów.

Jak wynika $z$ inwentarza szlachcica Aleksandra Balabana, dworzanina królewskiego i Anastazji Bujnowskiej z 1690 r., wpisanego do ksiąg grodzkich lwowskich, szlachcic ten był właścicielem zaledwie 12 książek nie wymienionych $z$ tytulu'.

Do rzadkości należeli przedstawiciele szlachty jak Piotr Ożga, referendarz koronny i starosta trembowelski w 1. 1609-1623, który miał trzysta książek?.

Kolekcjonerstwo książek rozkwitło na większą skalę w XVIII w. Przegląd XVIII-wiecznych księgozbiorów zacznę od jednej z największych w 1 ćwierci XVIII w. biblioteki Sobieskich w Żółkwi. Gromadzona przez pokolenia Sobieskich, Zółkiewskich, Daniłowiczów w XVI i XVII w. liczyła za czasów króla Jana III kilka tysięcy woluminów. Uważa się, iż księgozbiór prywatny króla Jana III liczył 7 tys. woluminów, chociaż nie wydaje się to pewne. Część jego przypadła 
w udziale królewiczowi Konstantemu, który przechowywał go na zamku żółkiewskim. Zbiory syna królewskiego w świetle inwentarza $z 1727 \mathrm{r}$. zawierały ok. 1200 woluminów, w tym sporo wydawnictw wielotomowych, część których nabył Konstanty w czasie podróży do różnych krajów. Wiele dzieł wydanych po śmierci Jana III wskazuje na królewicza Konstantego jako kontynuatora tradycji Sobieskich w gromadzeniu księgozbioru.

Warto odnotować, iż niewielki na razie fragment biblioteki Sobieskich, m.in. pochodzący ze zbiorów żółkiewskich, który swego czasu tralił do biblioteki Załuskich, został odkryty w Rosyjskiej Bibliotece Narodowej (dawnej Cesarskiej Bibliotece Publicznej) w Petersburgu.

Kolekcja Hieronima Orzechowskiego, kasztelana przemyskiego, której spis pochodzi z $1727 \mathrm{r}^{9}{ }^{9}$ liczyła około 130 tytułów. Inwentarz został podzielony na następujące działy, których nazwy nie zawsze odpowiadały zawartości: „Xięgi Rozne”, „Historici”, „Libri de legibus”, „Politici”, „Oratores”, „Panegires”, „Spirituales”, „Statistae”, „Medici” oraz „Economici”. W nim zostały zarejestrowane książki dotyczące historii, polityki, retoryki, religii, prawa, jak również nauk przyrodniczych, przeważnie w języku łacińskim, kilka w języku francuskim oraz polskim, jedna w czeskim. Na uwagę zasługuje podana na końcu inwentarza „Xięga malarska $z$ roznemi abrysami”.

W bibliotece domowej znajdowały się dzieła historyczno-polityczne Niccolo Machiavellego, Piusa II, Pawła Manucjusza, Karola Sigoniusa, a z polskich autorów: Reinholda Heidensteina, Krzysztofa Warszewickiego, Ewerharda Wassenberga, Pawła Piaseckiego, Mikołaja Chwałkowskiego i in., dzieła autorów klasycznych. Wśród autorów, piszących na tematy prawnicze w spisie książek widnieją nazwiska Jana Herburta, Jana Łaskiego i in.

Z 1. połowy XVIII w. znamy kilka innych bibliotek domowych, a wśród nich najwięlkszą znajdującą się w Cucułowcach koło Zydaczowa w ziemi lwowskiej Jerzego Stanisława Dzieduszyckiego (zm. w 1730 r.), koniuszego wielkiego koronnego, starosty żydaczowskiego, polityka, znającego killka języlków (łacinę, francuski, włoski, niemiecki, hiszpański a nawet turecki). Syn wojewody podolskiego Franciszka oraz Zofii $z$ Jabłonowskich Jerzy Stanisław interesował się różnymi dziedzinami wiedzy, m.in. historia, literaturą antyczną, prawodawstwem oraz wojskowością. W młodości zwiedzil kilka krajów zachodnioeuropejskich interesując się szczególnie sztuką oblężniczą. W późniejszym okresie będąc w roli posła odwiedził szereg dworów w Austrii (Wiedeń) oraz Wloszech (Rzym, Wenecja, Florencja, Parma, Genua i in.). Wojażował również w orszaku posła Rafała Leszczyńskiego do Turcji. Zniechęcony polityką uporlobał sobie dzierżawioną przez niego wieś Cucułowce, w której urządził wzbudzającą podziw rezydencję, park, bibliotekę oraz muzeum. Byl dobrym mówcą, znał doskonale łacinę, parał się też piórem.

Biblioteka liczyła według niektórych autorów $3585^{10}$, według innych $3565^{11}$ dzieł i zawierała piśmiennictwo niemal ze wszystkich dzieclzin wiedzy, głównie jednak nauk humanistycznych. Ten magnat, dyplomata, przebywający w różnych krajach już w 1686 r. posiadał bibliotekę. Książki były sygnowane „Ex Bibliotheca Dzieduszyciana" a $z$ księgozbioru korzystali ludzie pióra, m.in. biskup Józef Anclrzej Załuski. Może cllatego, jak pisze autor biogramu koniuszego, "niektóre książki wsiąkły do zbior u Załuskich" ${ }^{12}$. Z jego biblioteki wypożyczali 
książki również inni znajomi, a prawdopodobnie Benedylkt Chmielowski, sąsiad starosty z niedalekiego Firlejowa, który w „Nowych Atenach” uwiecznił wspaniałości pałacu w Cucułowcach oraz na wzór napisów istniejących w ogroclach w Cucyłowcach tworzył słynne w owym czasie „inskrypcje firlejowskie”. Autor „Nowych Aten”, uczeń kolegium jezuickiego we Lwowie, wykorzystując zasoby różnych bibliotek dotarł zapewne do księgozbioru swego sąsiada albo wyzyskał jego zbiory przechowywane po śmierci właściciela u jezuitów lwowskich. Wskazują na to tytuły niektórych rzadkich dzieł znajdujących się w inwentarzu Jerzego Dzieduszyckiego (np. figurujące jako „Gyllii de Constantinopoleos topographia") oraz figurujące w spisie książek wykorzystanych w „Nowych Atenach".

Ciekawy jest podział językowy biblioteki. R. Aftanazy podaje opierając się na Kronice domowej Dzieduszyckich ${ }^{13}$, iż w bibliotece, która liczyła w 1731 r. 3585 clzieł, w języku polskim znajclowało się 188, łacińskim 1490, francuskin 1230, wloskim 593, hiszpańskim - 27, niemieckim - 1 oraz 26 ksiązel $z$ rycinami. Do nauki języków arabskiego i hebrajskiego słuzyły gramatyki tych języków („Grammatica Hebraica” oraz „Rudimenta arabicae linguae").

W bibliotece znajdowały się ponad 50 rękopisów, w większości w języku włoskim (głównie $z$ zalkesu polityki oraz dziejów współczesnych Kościoła), kilkanaście w języku łacińskim (przede wszystkim o charakterze szkolnym), kilka w języku francuskim i polskim (m.in. z zakresu retoryki). Wśrócl rękopisów zasługuje na wymienienie Biblia pergaminowa („Biblia manuscripta in pargameno"), dzieło Długosza (,Annales Długossii. Manuscript[um]") oraz zbiór pism kardynała J. Mazarina w 4 tomach w języlku włoskim („Lettere del cardinal Masarini. Manuscript[um]").

Książki drukowane to druki głównie $z$ historii, filologii, polityki, prawa, literatury pięknej (głównie francuska, ale też włoska i polska). Literaturę starożytną reprezentowali niemal wszyscy najbardziej znani pisarze, wśród nich sporo było greckich. Oprócz nich występują autorzy czasów nowożytnych: Boccaccio, Petrarcha, Giambattista Marino, Rabelais, Montaigne, La Fontaine, Molier in. Były też dzieła zakresu heraldyki, wojskowości (kilkanaście pozycji reprezentują problematykę fortyfikacji). Posiadał kilka dzieł Niccolo Machiavellego w języku włoskim i francuskim (co można uważać za nieprzeciętne zainteresowanie tym autorem), w tym kilkutomowe wydanie jego dzieł oraz trzy wydania Księcia.

$\mathrm{Z}$ polskich autorów figuruje killkadziesiąt nazwisk pisarzy, historyków, polityków, prawników, uczonych od Długosza począwszy i na autorach pierwszej ćwierci XVIII w. skończywszy. Wśród nich warto wymienić nazwiska następujących autorów: Stanisław Orzechowski, Marcin Kromer, Jan Innocenty Petrycy, Łukasz Opaliński, Joachim Pastorius, Stanisław Kobierzycki, Jan Jonston, Szymon Starowolski, Jan Dymitr Solikowski, Jakub Sobieski, Jan Herburt, Jerzy Ossolinski, Paweł Szczerbic, Wawrzyniec Goślicki, Maciej Kazimierz Sarbiewski, Józel Andrzej Załuski, Andrzej Maksymilian Fredro. Warto podkreślić obecność dzieła M. Kopernika De revolutionibus orbium coelestium.

Starosta zydlaczowski sporo posiadlal dzieł z zakresu historii powszechnej m.in. dzieła dotyczące państw i krajów europejskich (Anglii, Italii, Francji, Hiszpanii, Austrii, Niemiec, Węgier, Litwy, Polski, Państwa Moskiewskiego i in.) oraz 
Turcji, Chin, Indii Zachodnich. Nie zabrakło też dzieł o dziejach narodów (np. Gotów), rodzin królewskich i książęcych, o wojnach, wodzach etc. Sporo posiadal dziel o charakterze biograficznym oraz pamiętników. Warto wymienić nazwiska kilku najbardziej znanych autorów, a więc: Philippa de Conmynes, Jakuba Augusta cle Thou, Karola Sigoniusa.

$\mathrm{Z}$ innych dziedzin posiadał niemało książek, m.in. $z$ literatury politycznej (ponad sto), filozofii (np. dzieła Descartes'a), retoryki. Nie brakowało nazwisk uczonych tej miary co Pascal. Nie zabrakło autorów reprezentantów prawa (Justynian, Hugo Grotius i in.), historii Kościoła (Baroniusz), żeby wymienić imiona tylko nielktórych najważniejszych.

W inwentarzu figurują nawet dzieła literatury heroiczno-miłosnej, jak Argenida Johna Barclaya w przeróbce W. Potockiego („Historia o Argeniclzie krolowey Sicilyiskiey”) oraz popularne powieściowe utwory („O dziejach Alexandra Wielkiego historia”, „Historia Meluzyny”), przeznaczone głównie dla mniej przygotowanych czytelników (głównie kobiet).

Po śmierci właściciela biblioteka została przelkazana OO. Jezuitom lwowskim i w kilka lat później spłonęła razem ze zbiorani jezuickimi ${ }^{14}$.

Księgozbiór o nieznanej wielksości posiadali hrabiowie Tarnowscy w pierwszej połowie XVIII w. Zajewne część tej biblioteki znajlowała się w $1730 \mathrm{r}$. w Cuculowcach u starosty żydaczowskiego, jak świadczy o tym następujący zapis podany przy końcu inwentarza ksiązek Jerzego Dzieduszyckiego: „Oprocz wyzej specyfikowanych ksiąg w teyze bibliotece w szafie osobliwey byli księgi WW Im[...] panow hrabiow Tarnowskich, te co w osobliwą skrzynię zamknięte, zapieczetowane y maią po nich przysłać WW Imc panowie lurabiowie Tarnowscy, iako iusz ich rewidowali y swoią pieczęcią zapieczętowali".

W Wiśniowcu leżącym w województwie wołyńskim, Michal Serwacy Wiśniowiecki (zm. 1744) zgromadzil ok. $1400^{15}$ książek, głównie w języku w łacińskim i francuskim. Biblioteka w Wiśniowcu dostała się w spadku Mniszchom (dziś fragment przechowywany jest w Bibliotece Narodowej Ukrainy w Kijowie).

Rodzina Mniszchów zgromadziła w kilku miejscowościach sporej wielkości księgozbiory. Ich biblioteka znajdująca się w Laszkach Murowanych, położonych niedaleko Lwowa w $1748 \mathrm{r}$. liczyła ponad 1000 książek $z$ różnych dziedzin wiedzy $^{16}$. Wśród nich znajdowały się dzieła $z$ techniki, obronności, sporo kalendarzy oraz ręlkopisy.

Najwięcej jednak wiadomości o bibliotekach posiadany $z$ drugiej połowy XVIII w.

Biblioteka ${ }^{17}$ Joachima Potockiego, pana na Czortkowie, komendanta fortec podolskich wedlug spisu z 1765 r. liczyła ok. 830 woluminów, w tym ok. 60\% dzieł w j. francuskim, resztę stanowiły książki polskie oraz lacinskie. Oprócz książek J. Potocki posiadal kilkadziesiąt map. Warto odnotować również kilka katalogów wydawniczych w języku francuskim, co można interpretować jako przejaw godnych podkreślenia zainteresowań kolekcjonerskich ich właściciela. Oprócz typowej dla tej wielkości biblioteki magnackiej literatury z różnych dziedzin, księgozbiór wyróżnia kolekcja książek dotycząca obronności, architektury, inżynierii oraz literatury pięknej w języku francuskim. Nawet literatura klasyczna występuje w tłumaczeniu na język francuski. 
Jedna z większych była kolekcja książek księcia Józefa Aleksandra Jabłonowskiego, wojewodly nowogródzkiego, którą przechowywał na Wołyniu i w ziemi halickiej (w Lachowcach, Podhorcach i Jabłonowie). Znalazły się w niej m.in. fragmenty księgozbioru Dantyszka, królewieckiej biblioteki miejskiej, kolekcji mieszkańca Królewca Daniela Salthena. Czterotomowy katalog tej biblioteki ukazal się drukiem w Lipsku w 1755 r. Biblioteka zawierała głównie książki historyczne oraz $z$ zakresu religii. Była udostępniana uczonym, jak M. Dogielowi i J. D. Janockiemu ${ }^{18}$.

W Podhorcach założył bibliotekę Wacław Rzewuski (zm. w 1779 r.), hetman wielki koronny, dziad Emira, który zgromadził wiele pamiątek po Sobieskich. Biblioteka liczyła w XVIII w. ok. 6000 tomów a przeważały w niej książki dotyczące sztuki wojennej ${ }^{19}$.

Nieduży księgozbiór Władysława Łuszczowskiego, starosty żydaczowskiego spisany w dniu 6 lutego 1763 r. po jego śmierci przez wdowę Cecylię z Rozwadowskich zawierał, jak wylkazał to inwentarz, ponad 80 dzieł (w tym dwa manuskrypty), wśród których znajclowało się 15 francuskich, 7 niemieckich oraz 30 lacińskich (wszystkie nie wymienione $z$ tytułu); polskich bylo mniej niz połowa, głównie $z$ zakresu literatury religijnej, kilka prawniczych (konstytucje), jedno dzieło autorstwa Jana Kochanowskiego (,Treny satyra przez Jana Kochanowskiego wydane”) oraz kalendarze („Kalendarzyków lat wszelakich In N[umer]o siedmnascie") ${ }^{20}$.

Nieco mniejsza byla biblioteka domowa Wojciecha Siemieńskiego, referendarza koronnego, który posiadał majątki w woj. ruskim (jak świadczy o tym inwentarz z $1765 \mathrm{r}$.) ${ }^{21}$, liczyla bowiem ok. 60 książek (w tym kilka ręlkopisów), głównie $z$ zakresu prawa, historii i religii. Wśród prawniczych znajdowały się m.in. statuty, konstytucje, herbarze (Okolskiego i Niesieckiego). Około 50\% stanowiły druki w języku polskim, reszta to głównie książki łacińskie. Oprócz tego w inwentarzu figurują dykcjonarze i gramatyki w języku francuskim i niemieckim.

Jako przykład ciekawego księgozbioru szlachcianek może służyć zarejestrowany w sądzie grodzkim halickim wykaz książek ${ }^{22}$ Abundancji Dąbrowskiej, primo voto Golejowskiej, $z$ domu Strumieńskiej, cześnikowej buskiej. Sporządzony w Haliczu 19 sierpnia 1739 r. jest jednym $z$ nielicznych spisów książek należących do kobiet, który zachował się w księgach sądowych południowowschodnich ziem dawnej Rzeczypospolitej. Jest on o tyle interesujący, iz daje pewien obraz zainteresowań czytelniczych szlachcianki I połowy XVIII w. Wśród książek należących do niej zarejestrowano 36 pozycji książkowych (wszystkie w języku polskim), $z$ czego jest znanych 37 tytułów dzieł, obok nieznanych liczebnie ksiązek zanotowanych jako „Xiązki litewskie mnie darowane za życia". W sumie zostało zarejestrowanych 93 woluminy, w tym spora liczba, bo aż 54 kalendarzy ${ }^{23}, z$ całą pewnością pochodzących $z$ różnych lat. $Z$ literatury pięknej figuruje 17 tytułów, religii - 14, meclycyny - 1, filozofii - 1, nieokreślonej dziedziny - 1 („Xiązka Dywertysment Mikołaia Potockiego”). Wśród książek z zakresu literatury pięknej znalazły się ulubione, zwłaszcza wśród czytelniczek, powieści („Historie”): Historia o Aleksandrze, Historia o Magielonie świadczące o popularności ich również na ziemi halickiej. Oprócz romansów rycerskich i innej popularnej literatury szlachcianka interesowała się heroiczno- 
miłosnymi powieściami barokowymi. W spisie figurują m.in.: Argenida Johna Barclaya w przeróbce W. Potockiego, Pastor fido w przekładzie Jerzego Sebastiana Lubomirskiego oraz jedna $z$ najlepszych powieści epoki barokowej Kolloander wierny Leonildzie przyjaźni dotrzymujący G. A. Mariniego.

Figuruje równiez poczytny w swoim czasie poemat Dafnis Samuela Twardowskiego.

Nie zabraklo popularnej również w księgozbiorach mieszczańskich Fortuny Seweryna Bączalskiego czy dzieł literatury mieszczańskiej (zanotowanych jako „Albertus xięzy pacholek” i „Seym Panienski”). Dwa dziełka Przemiany Owidiusza oraz Psyche (zapewne Jana Andrzeja Morsztyna) wypożyczył znajomy czy tez krewny („wziol Inc Pan Stolnik Ciechanowski”). Z dzieł religijnych oprócz zniszczonych przez częste używanie Zywotów świętych (zapewne Piotra Skargi) znajdowały się m.in. wydane osobno historie życia niektórych świętych.

Porównując wielkość księgozbiorów szlachty województwa krakowskiego, zbadanych w wyniku systematycznych kwerend Heleny Bogdanow, z zawartością domowych księgozbiorów jej przedstawicieli zamieszkałych na południowowschodnich terenach dawnej Rzeczypospolitej, należy stwierdzić, iz szlachta zamieszkała na ziemiach ruskich posiadlała większe i cenniejsze księgozbiory niz krakowska. Jeżeli w 102 inwentarzach szlachty krakowskiej z XVIII w. autorka doliczyła się w sumie około czterech tysięcy ksiązek ${ }^{24}$, to w wyniku przeprowadzonych wyrywkowych kwerend w aktach sądowych wzmiankowanych województw wschodnich Rzeczypospolitej można stwierdzić, iz tylko w kilkunastu księgozbiorach znajdowało się o wiele więcej druków. Jeżeli nawet, zarówno w jednym jak i w drugim przypadku, nie są to pełne dane (a tak nalezy uważać), to i tak widlać ogromną różnicę w wielkości posiadlanych bibliotek.

Podsumowując należy stwierclzić, iz dotychczasowe badania sondażowe wykazują, iż na południowo-wschodnich terenach Rzeczypospolitej znajdowały się spore - jak na warunki polskie - biblioteki bogatej szlachty. Weryfikacji więc należy poddać opinię niektórych badaczy (Władysław Łoziński), którzy twierdzili, iż w wojewóclztwie ruskim niewielu szlachty zbierało książki, w odróżnieniu od innych form alktywności, związanych m.in. z fundowaniem kościołów i klasztorów. Sprawa systematycznych badań nad inwentarzami szlachty na ziemiach południowo-wschodnich dawnej Rzeczypospolitej, które winny być przeprowadzone w księgach grodzkich i ziemskich znajdujących się dziś w archiwach Lwowa i Kijowa, jest zadaniem zarówno koniecznym, jak i pilnym.

Należy stwierdzić, iz lssięgozbiory magnaterii zawierały w XVI-XVII w. średnio kilkaset ksiązek, w XVIII w. liczba ich zwiększyła się w poszczególnych przypadkach nawet do kilku tysięcy; szlachta średnia natomiast posiadała księgozbiory liczące od kilkunastu do kilkudziesięciu woluminów, rzadko killkaset. Nie wszyscy jej przedstawiciele posiadali książki. Szlachta uboga natomiast albo w ogóle nie miała książek, albo też jedynie pojedyncze egzemplarze modlitewników i żywotów świętych. Wskutek napadów wrogów ulegały zniszczeniu niektóre kolekcje książek. I tak spora biblioteka znajdowała się na zamku w Uchaniu, miejscowości Cetnerów, leżącej w województwie bełskim, która częściowo została zniszczona a po części zrabowana przez przechodzące wojska szwedzkie i moskiewskie, jak świadczy o tym urzędowa wizja z 5 listopada $1718 \mathrm{r}^{25}$. 
Na końcu warto podkreślić znaczenie rezydencji magnackiej oraz dworu szlacheckiego w kulturze polskiej. Dwór był tworem o charakterze autonomicznym i ośrodkiem szeroko pojętej kultury, nie tylko umysłowej. Biblioteka znajdująca się w nim pełniła różnorakie funkcje: poznawcze, oświatowe, rozrywkowe i to nie tylko dla właścicieli i domowników, ale także dla krewnych, społeczności sąsiedzkich, wreszcie ludzi pióra. Dlatego jej znaczenie dla otoczenia, bliższej i dalszej okolicy trudno przecenić.

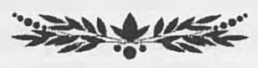

\section{Przypisy:}

${ }^{1}$ U. Paszkiewicz, Rekopiśmienne inwentarze $i$ katalogi bibliotek z ziem wschodnich Rzeczypospolitej (spis za lata 1553-1939), Warszawa 1996; tejże: Inwentarze $i$ katalogi bibliotek z ziem wschodnich Rzeczypospolitej (spis za lata 1510-1939), Warszawa 1998; tejże: Inwentarze i katalogi bibliotels z ziem wschodnich Rzeczypospolitej do roku 1939, Suplement 1, Warszawa 2000.

${ }^{2}$ Por. m.in. Biblioteka Zakladu Narodowego im. Ossolińskich we Wroclawiu, rkps. 217/77 (Materialy Józefa Skoczka), s. 278.

${ }^{3} \mathrm{O}$ bibliotece Zamoyskich zob. m.in. Slownik pracowników książki polskiej, Warszawa-Łódź 1972 (dalej-SPKP), s. 1007.

${ }^{4}$ W. Łoziński, Życie polskie w dawnych wiekach, Kraków 1974, s. 35.

${ }^{5}$ Spis książek znajduje się $w$ archiwum Lanckorońskich (Centralne Państwowe Archiwum Historyczne Ukrainy we Lwowie - dalej CPAHUL, fond (f.) 181, opis (op.) 2, sprawa (spr.) 241).

${ }^{6}$ CPAHUL, f. 9 (Castrensia Leopoliensia), op. 1, spr. 457, s. 262.

${ }^{7}$ W. Eoziński, Prawem $\mathrm{i}$ lewem, t. 1, Kraków 1960, s. 25.

${ }^{8}$ Więcej na temat księgozbioru Sobieskich w artykule autora tego tekstu $O$ księgozbiorze Sobjeskich w związku $z$ inwentarzami bibliotek Jana III oraz królewicza Konstantego Wladysława Sobieskiego przygotowanym do Ksiegi Jubileuszowej poświęconej Prof. Paulinie Buchwald-Pelcowej (w druku).

${ }^{9}$ CPAHUL, f. 15 (Castrensia Sanocensia), op. 1, spr. 224, s. 2408 i nn.

${ }^{10}$ Według wstẹpnych obliczeń w inwentarzu książek Jerzego Dzieduszyckiego znajdowalo się nieco ponad 3500 druków j rękopisów (CPAHUL, f. 7 (Castrensia Zydaczoviensia), op. 1, spr. 102, s. 161 i nn.).

${ }^{11}$ F. Radziszewski, Wiadomość historyczno-statystyczna o znakomitszych bibliotekach $i$ archiwach publicznych i prywatnych..., Kraków 1875, s. 8; SPKP, s. 194 (J. Długosz).

${ }^{12}$ Polski słownik biograficzny, t. VI, (red.), W. Konopczyński, Kraków 1948, s. 111, (W. Konopczyński).

${ }^{13}$ [M. Dzieduszycki], Kronika domowa Dzieduszyckich, Lwów 1865, s. 187; R. Aftanazy: Dzieje rezydencji na dawnych kresach Rzeczypospolitej, t. 7: Województwo ruskie. Ziemia Halicka i lwowska, Wroclaw-Warszawa-Kraków 1995, s. 289.

${ }^{14}$ O J. S. Dzieduszyckim i jego księgozbiorze zob. m.in. w: SPKP, s. 194 (J. Długosz). 
${ }^{15}$ Por. Slownik pracowników ksiazzki polskiej. Suplement (dalej - SPKP Suplement ) Warszawa-Łódź 1986, s. 231 (W. Sulikowska), R. Aftanazy, Dzieje rezydencji na dawnych kresach Rzeczypospolitej, t. 5, Województwo wołyńskie, Wrocław-Warszawa-Kraków 1994, s. 535.

${ }^{16}$ Obliczenia na podstawie opracowania: Materialy żródlowe do dziejów kultury i sztuki XVI-XVIII w, zebrad i opracował: M. Gębarowicz, Wroclaw-Warszawa-KrakówGdańsk 1973, s. 56 i nn.

${ }^{17}$ Jej inwentarz zob. CPAHUL, f. 9 (Castrensia Leopoliensia), op. 1, spr. 599.

${ }^{18} \mathrm{O}$ niej zob. SPKP, s. 351 (B. Leytner). Biblioteka lodowa Jabłonowskich byla przedmiotem badań i tematem pracy kandydackiej (obronionej w 1999 r. w Kijowie) Svithany Bulatowej.

${ }^{19}$ SPKP, s. $781-782$ (T. Krzyżewski).

${ }^{20}$ CPAHUL, f. 5 (Castrensia Haliciensia), op. 1, spr. 281, s. 319-320.

${ }^{21}$ Ibidem, f. 9 (Castrensia Leopoliensia), op. 1, spr. 599, s. 175-176.

${ }^{22}$ Ibiclem, fond (f.) 5 (Castrensia Halicensia), opis (op. 1), sprawa (spr.) 243, s. 14631464.

${ }^{23}$ „Kalędarzow w iednym związku Trzydziesci y Dwa. Kalędarzow w Drugim Związku Dwadziescia y Dwa" (ibidem, s. 1463).

${ }^{24}$ Por. H. Bogdanow, Literatura spoleczno-polityczna jako wyraz zainteresowań szlachty krakowskiej w XVIII w: „Studia o Książce”. t. 3, s. 346.

${ }^{25}$ CPAHUL, f. 181 (archiwum Lanckorońskich), op. 2, spr. 247, k. 14v, 15, $20 \mathrm{v}, 21$. 